\title{
Provenance and geochemistry of exotic clasts in conglomerates of the Oligocene Torehina Formation, Coromandel Peninsula, New Zealand
}

\author{
GEORGE R. DIX \\ Ottawa-Carleton Geoscience Centre \\ Department of Earth Sciences \\ Carleton University \\ 1125 Colonel By Drive \\ Ottawa, Ontario, Canada K1S 5B6 \\ email: gdix@ccs.carleton.ca
}

\section{CAMPBELL S. NELSON}

Department of Earth Sciences

University of Waikato

Private Bag 3105

Hamilton, New Zealand

\begin{abstract}
Non-marine pebble to cobble conglomerates of the lower Torehina Formation (Oligocene) crop out along western Coromandel Peninsula and overlie, with strong angular discordance, continental-margin metasedimentary rocks (Manaia Hill Group) of Mesozoic (Late Jurassic to ?Early Cretaceous) age. The conglomerates contain provenance information that identifies a pre-Oligocene depositional history obscured by the unconformable juxtaposition of these Tertiary and Mesozoic strata.
\end{abstract}

Most clasts in the lower Torehina Formation are visually similar to local bedrock lithologies, including metamorphosed sandstones and argillites, but are kaolinitic and contain more detrital and authigenic chert, quartz, and potash feldspar. Local derivation of these clasts seems unlikely. By comparing geochemical ratios with those defined for continental margin sandstones, and well characterised New Zealand tectonic terranes, we interpret the majority of clasts in the lower Torehina Formation to have been derived from a dissected orogen, with mixtures of felsic and volcanogenic-derived sediment. The most likely sources are the Waipapa and Torlesse Terranes.

The remaining 20-30\% of the clasts in the lower Torehina Formation were originally friable, are coarse grained, and appear to be lithologically exotic relative to known metamorphosed sandstones in basement terrane sources on North Island. Some clasts contain coal laminae and particles, and all contain detrital kaolinite as lithic fragments and matrix. Such characteristics imply a non-marine to marginalmarine source containing sediment derived from strongly weathered granite or granodiorite. Mechanical fragility implies a likely proximal, easily erodible source. We propose that this group of clasts was derived from an Upper Cretaceous sedimentary cover, either part of a locally developed basin fill or part of a once regionally extensive

G02021; Online publication date 13 November 2003

Received 15 April 2002; accepted 19 May 2003 cover on North Island. Either case defines a more widely distributed Cretaceous source than found today.

Keywords Coromandel Peninsula; Torehina Formation; Oligocene; conglomerate; pebble composition; pebble geochemistry; provenance; Cretaceous; Manaia Hill Group; Waipapa and Torlesse Terranes

\section{INTRODUCTION}

On Coromandel Peninsula, North Island (Fig. 1), conglomerates of the Oligocene Torehina Formation (Kear 1955) overlie with angular unconformity deep-water continental margin metasedimentary (greywacke) strata of the Jurassic to ?Early Cretaceous Manaia Hill Group (Fig. 2) (Skinner 1972; Black 1994; Mortimer 1995a). The unconformity identifies an apparent lengthy lacuna, c. 12070 m.y., that encompasses deformation, uplift, and erosion of basement strata during the Rangitata Orogeny in Early Cretaceous time (Suggate et al. 1978). However, pebble to cobble size clasts in conglomerates of the lower Torehina Formation include a significant amount (20-30\%) of a lithology not obviously derived from the local or regional bedrock. Instead, the lithology is more similar to postorogenic Late Cretaceous sandstones and conglomerates that crop out in areas removed from Coromandel Peninsula, North Island.

We interpret the provenance of clasts contained in lower Torehina conglomerates by comparing their petrography and element (major, trace, REE) geochemistry with several endmember petrofacies: (1) local basement rocks; (2) Late Cretaceous "suprabasement" strata (Suggate et al. 1978); (3) continental margin sandstones derived and deposited in various tectonic settings (e.g., Bhatia 1985; Bhatia \& Crook 1986; Roser \& Korsch 1986, 1988; McLennan et al. 1990); (4) petrological changes attending chemical weathering (Nesbitt \& Young 1982, 1989); and (5) petrogenetic characteristics of tectonic terranes that underlie North Island (Fig. 1) (Roser \& Korsch 1986, 1988, 1999; Mortimer 1995b; Mortimer et al. 1997).

\section{GEOLOGICAL SETTING}

The study area lies on the west coast of central Coromandel Peninsula, structurally the eastern margin of the Hauraki Rift that underlies the Hauraki Gulf (Fig. 1, 3A) (Hochstein \& Nixon 1979). The Torehina Formation is an isolated lithostratigraphic equivalent to the geographically widespread terrestrial and shallow-marine transgressive deposits of the mid-Tertiary Te Kuiti Group of central western North Island (Kear \& Schofield 1958; Nelson 1978; Suggate et al. 1978). The Torehina Formation, likewise, records onlap of non-marine, then marine sediment onto the basement 


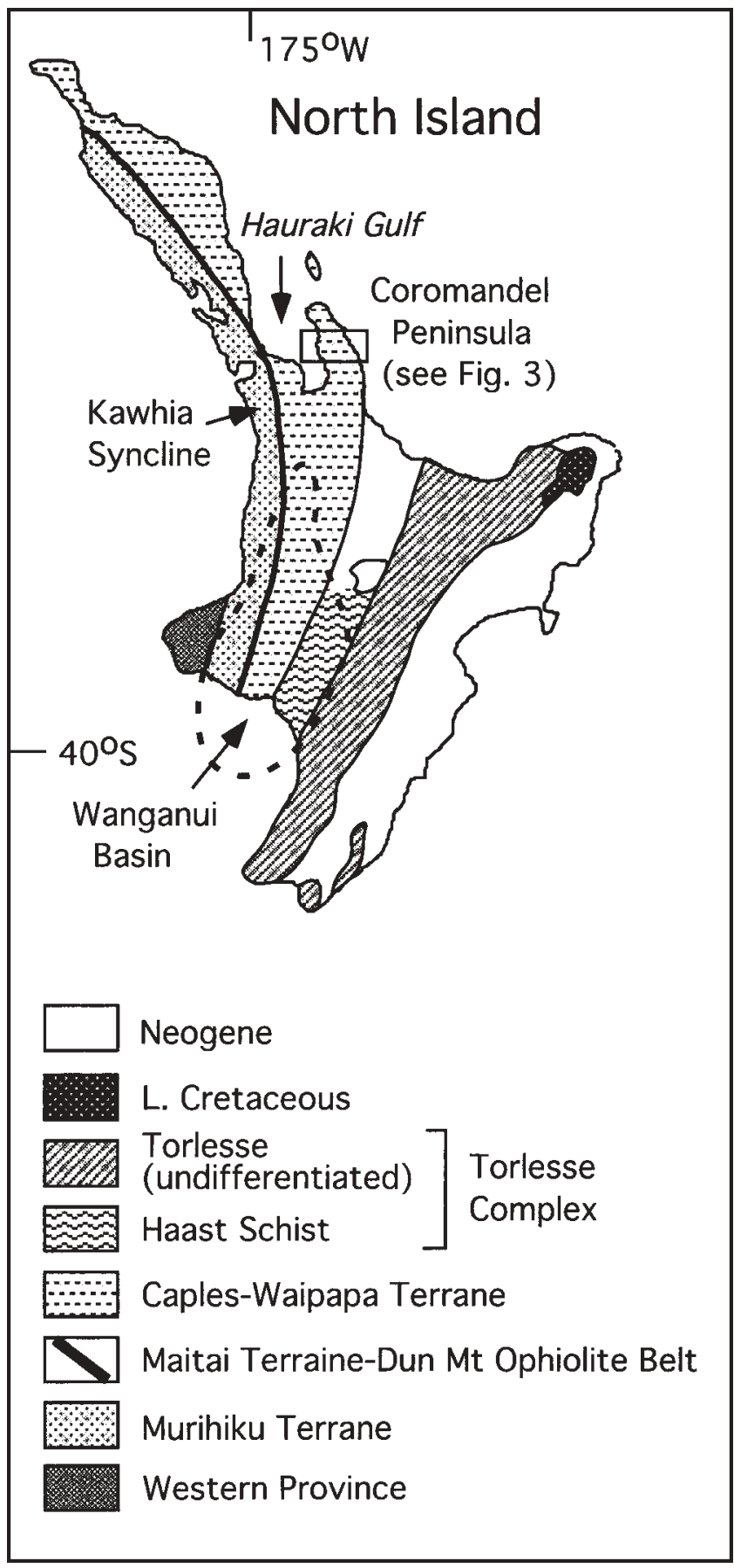

Fig. 1 Location of study area on Coromandel Peninsula, North Island, shown relative to distribution of Mesozoic basement terranes, general areas of suprabasement (Neogene, Late Cretaceous) strata, outline of the Wanganui Basin, and main area of Kawhia Syncline. Based on Kamp \& Liddell (2000) and Mortimer et al. (1997).

Manaia Hill Group (Fig. 3B, 4) (Kear 1955; Skinner 1976). Torehina strata form small erosional remnants (Fig. 3) of a once more widespread sedimentary cover. Locally, basal coalbearing strata contain an early Oligocene palynoflora (Isaac et al. 1994), whereas younger calcareous (marine) strata in the main outcrop area (Fig. 3B) define a late Oligocene age (Hayward et al. 1990; Dix \& Nelson in press).

The Manaia Hill Group lies within the Caples-Waipapa Terrane (Fig. 1) (Black 1994; Roser \& Korsch 1999).

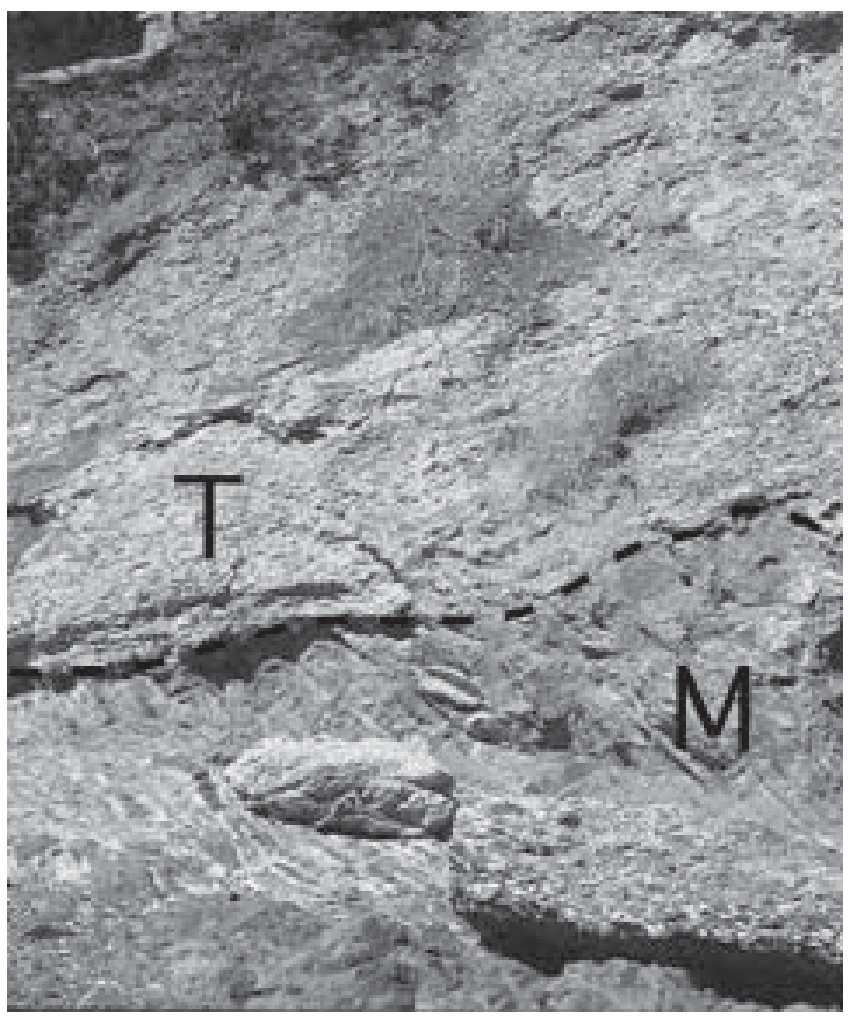

Fig. 2 Coastal exposure (Fig. 3B, locality D) of the angular unconformity separating conglomerate of the Torehina Formation (T) from the underlying Manaia Hill Group (M). Horizontal distance is c. $5 \mathrm{~m}$.

Tectonic amalgamation and deformation of several terranes that now underlie North Island (Fig. 1) occurred by Early Cretaceous time (Black 1994; Mortimer 1995a; King et al. 1999). These terranes range in age from Permian to ?Early Cretaceous, and, as now found across North Island, there is a general west-to-east gradient of decreasing volcanogenic facies from a westerly magmatic arc (Black 1994; Mortimer 1995a; Roser \& Korsch 1999).

The Manaia Hill Group extends across Coromandel Peninsula and contains metamorphosed lithic volcanic wackes, mudrocks, and conglomerates. Autogenous oceanic (basalt) material is lacking, although minor authigenic chert is present (Skinner 1972, 1976). In the northern part of the peninsula, the Manaia Hill Group is represented by the Moehau Formation. In the central part, the equivalent Matawai Formation grades upward into interbedded argillite and metawacke of the Tokatea Formation, which defines the upper Manaia Hill Group (Skinner 1993), and contains more abundant felsic, non-volcanic, and weathered detritus (Skinner 1972, 1993). Moving farther south, correlative metamorphic strata of the Manaia Hill Group possess increased quartzofeldspathic content or are of a mixed volcanic and "granitic" provenance, and locally contain plant fragments (Skinner 1978).

Coal-bearing strata as source rocks are relevant to our study. Possible Mesozoic source rocks include two general sources: (1) Upper Cretaceous strata of non-marine and marine origins on North Island, today distributed along its eastern margin (Fig. 1) (Kingma \& Speden 1978) and in the subsurface along its western margin (Laird 1993); and (2) within metamorphosed sandstones of the Murihiku and 
Fig. 3 A, Distribution of the Torehina Formation (black) in central Coromandel Peninsula, and study area (box outline). B, Detailed bedrock geology in the study area, showing sample site locations (A-G). Regional geology after Skinner (1976).
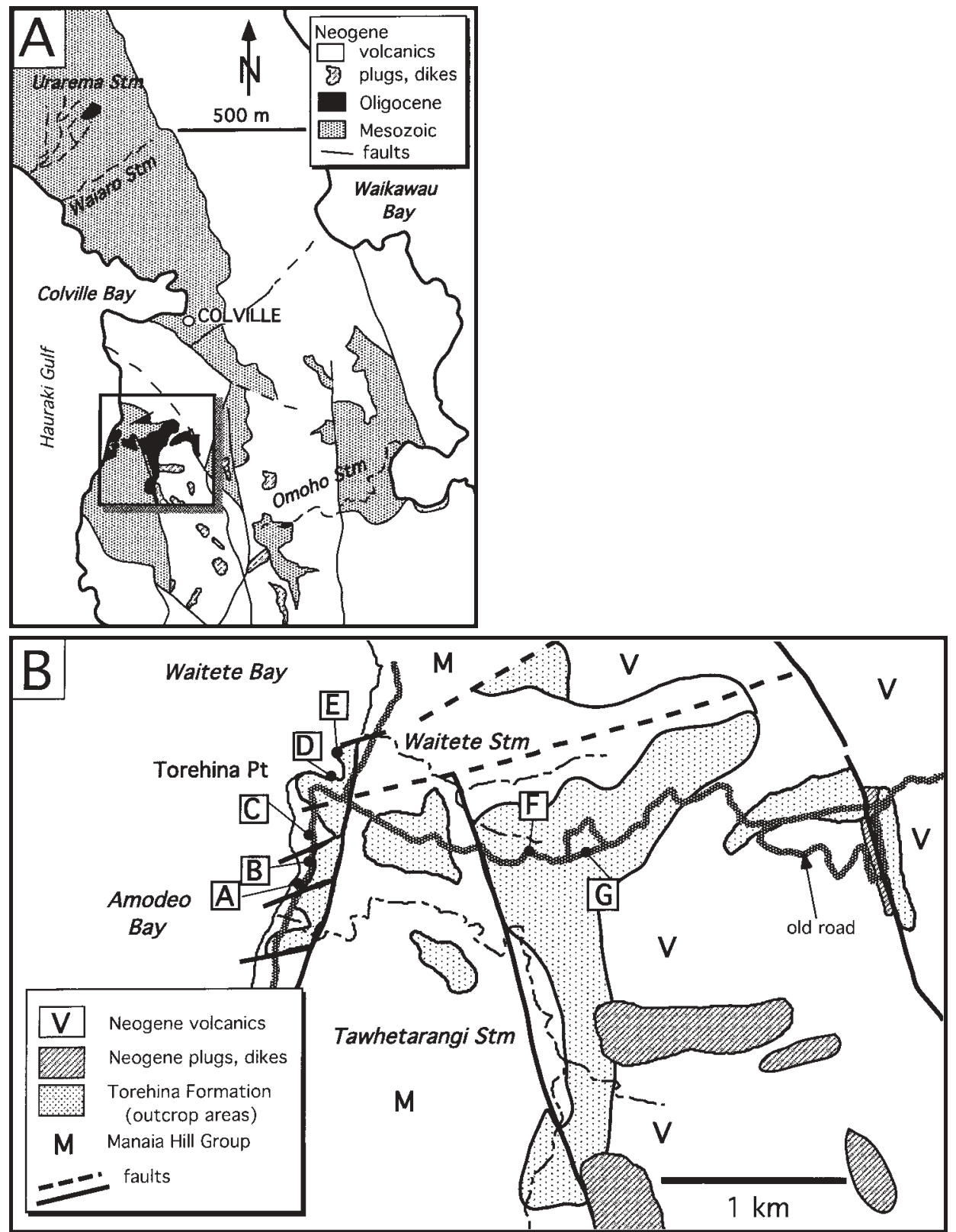

Torlesse Terranes west and south, respectively, of the study area (Ballance 1988; Baker \& Staveley Parker 1989).

\section{METHODS}

The main suite of clasts studied was collected from basal conglomerates exposed at locality D (Fig. 3B, 4), the prominent coastal exposure of the Torehina Formation (Kear 1955). In addition, samples of sandstone interbedded with conglomerate, and a sample of the sandy matrix of a conglomerate bed, were taken from this same locality. Other samples of pebbles and lower Torehina sandstones were taken from nearby coastal sites (Fig. 3B, 4, locations A-C). Our remaining samples are of a very fine grained sandstone to sandy siltstone that overlies a prominent paleokarst surface exposed at localities $\mathrm{F}$ and $\mathrm{G}$, and calcareous siltstone at locality E (Fig. 3B, 4).
At locality D, cross-sectional views $\left(1 \mathrm{~m}^{2}\right)$ of conglomerate beds were photographed for point-count analysis. Sandstone terminology follows Dott (1964). Thin sections were stained with sodium cobaltinitrate to identify potash feldspar (Hutchinson 1974). Statistical measure of sediment constituents was determined by point-counting 300 points per thin section. Mineralogy was confirmed using powder X-ray diffractometry (Carleton University). Clasts trimmed of surface weathering were analysed for major, trace, and rare earth elements. Samples were powdered, then subdivided: one sample (1.5 g) was used for major element analysis using standard X-ray fluorescence procedure (XRF; University of Ottawa, Canada); the other part was used for trace and rare-earth element (REE) analysis using conventional ICP-MS procedures (Ontario Geological Survey, Canada). A comparison of clast and local basement rock lithotypes is given in Table 1. Summaries of geochemical variation for clast and sediment types in the Torehina Formation are provided in Tables 2 and 3. 


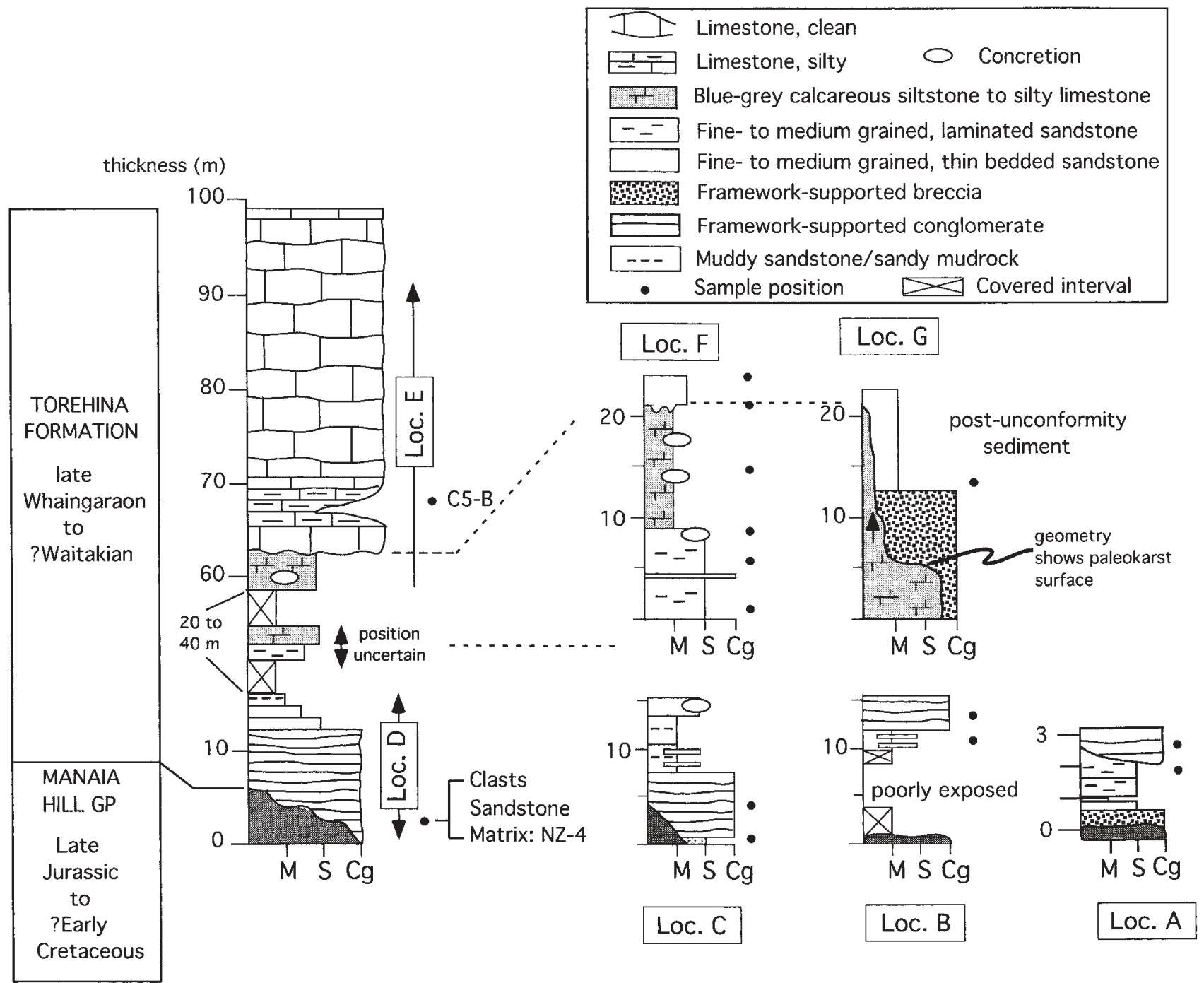

Fig. 4 Stratigraphic sections and distribution of sample positions (black solid circles). Specific samples referred to in the text are indicated. Width of a column refers to general grain size of siliciclastic rocks: $\mathrm{M}$, mudstone; $\mathrm{S}$, sandstone; and $\mathrm{Cg}$, conglomerate, and intermediate sizes.

Table 1 Selected petrological characteristics of clasts of apparent metasedimentary basement terrain affinity (TA) and unknown affinity (UA) within the lower Torehina Formation, compared to metamorphosed sandstones of the local Manaia Hill Group (Skinner 1972).

\begin{tabular}{|c|c|c|c|}
\hline & Manaia Hill Group & TA clasts & UA clasts \\
\hline Colour & Dark blue-grey & Medium-dark grey & Light grey \\
\hline Hardness & Very indurated & Well indurated & Firm to friable \\
\hline Texture & Fine-grained sst & Fine-grained sst & $\begin{array}{l}\text { Medium to } \\
\text { coarse grained sst }\end{array}$ \\
\hline Plag./total feldspar & $>0.75$ & Often $<<0.30$ & Often $<<0.30$ \\
\hline Matrix content & $25-80 \%$ & $15-25 \%$ & $25-50 \%$ \\
\hline $\begin{array}{l}\text { Matrix } \\
\text { composition }\end{array}$ & $\begin{array}{l}\text { Quartz, feldspar, } \\
\text { chlorite, calcite }\end{array}$ & $\begin{array}{l}\text { Sericite } \\
\text { Quartzose }\end{array}$ & $\begin{array}{l}\text { Illite } \\
\text { Kaolinite }\end{array}$ \\
\hline $\begin{array}{l}\text { Replacement } \\
\mathrm{CaCO}_{3}\end{array}$ & $\begin{array}{l}\text { Present to common } \\
\text { (up to } 60 \% \text { ) }\end{array}$ & Rare & Absent \\
\hline $\begin{array}{l}\text { Detrital and/or } \\
\text { replacement chert }\end{array}$ & Absent to minor & Common & Present \\
\hline $\begin{array}{l}\text { Sedimentary } \\
\text { lithoclasts }\end{array}$ & Some $(<15 \%)$ & $\begin{array}{l}\text { Present to } \\
\text { common }(<40 \%)\end{array}$ & $\begin{array}{l}\text { Present to } \\
\text { common }(<40 \%)\end{array}$ \\
\hline
\end{tabular}




\section{PETROGRAPHIC ATTRIBUTES}

Table 1 presents the prominent petrogenetic characteristics of Torehina clasts from our study compared to those of Manaia Hill Group strata (Skinner 1972). There are differences between values of plagioclase/total feldspar ratio, carbonate content, matrix composition, and abundance of detrital and authigenic chert (Table 1). For purposes of the following data presentation and discussion, we consider two broad clast types: (1) specimens with lithology and texture similar to local metasedimentary basement facies are referred to as having a "terrane affinity" (TA); and (2) specimens that are clearly not derived from local source are part of an exotic suite of "unknown affinity" (UA).

\section{Local basement}

Metamorphosed sandstones of the local Manaia Hill Group are very indurated and fine grained $(<100 \mu \mathrm{m})$. Weathered, they have a brownish colour, whereas fresh surfaces are dark bluish-grey. Typical textures include angular to subrounded volcanic and sedimentary lithic fragments, with more angular quartz, potash feldspar, and minor amounts of plagioclase. Regionally, basement rocks are crosscut variably by calcite veins often distributed in local shear zones, otherwise they lack carbonate (Skinner 1972). In our study area, carbonate is locally abundant (50-60\%), replacing particles and matrix even where shearing zones are not evident. The origin and timing of the replacement process remain uncertain, but its presence is anomalous relative to the regional paucity of carbonate (excluding shear zones) in the Manaia Hill Group (Skinner 1972, 1993), and absence of any calcareous basement-derived clasts in the Torehina conglomerates. We have not included carbonate-bearing basement rocks in our TA suite of clasts used for geochemical analysis.

Table 2 Selected geochemical data of clast types (UA = uncertain source affinity; TA = basement terrane affinity) and three sediment groups from the Torehina Formation. Mean and 95\% confidence interval (in brackets) values are shown for major element oxides, selected trace elements, loss on ignition (LOI), and chemical index of alteration (CIA). Selected ratios and 95\% confidence intervals (rounded to nearest integer) are included. Other information: number $(n)$ of samples per category; $\mathrm{ND}=$ not determined; $\mathrm{Nd}=$ not detected; $\mathrm{NI}=$ indeterminate.

\begin{tabular}{|c|c|c|c|c|c|}
\hline & \multicolumn{2}{|c|}{ Clasts } & \multirow[b]{2}{*}{$\begin{array}{l}\text { Post-unconformity } \\
\qquad n=3\end{array}$} & \multicolumn{2}{|c|}{ Sediment } \\
\hline & $\begin{array}{c}\text { TA } \\
n=6\end{array}$ & $\begin{array}{l}\text { UA } \\
n=9\end{array}$ & & $\begin{array}{l}\text { Siltstone } \\
\quad n=1\end{array}$ & $\begin{array}{c}\text { Lower sandstone } \\
\quad n=9\end{array}$ \\
\hline $\mathrm{SiO}_{2}(\%)$ & $73.05(1.80)$ & $70.31(2.56)$ & 71.44 (1.68) & 19.63 & $79.45(2.91)$ \\
\hline $\mathrm{TiO}$ & $0.70(0.08)$ & $0.82(0.10)$ & $0.57(0.09)$ & 0.11 & $0.47(0.07)$ \\
\hline $\mathrm{Al}_{2} \mathrm{O}_{3}$ & $14.78(1.28)$ & $15.81(1.44)$ & 11.99 (1.39) & 2.45 & $10.48(1.40)$ \\
\hline $\mathrm{Fe}_{2} \mathrm{O}_{3}$ & $0.64(0.09)$ & $0.95(0.44)$ & $3.25(2.06)$ & 1.37 & $1.25(0.55)$ \\
\hline $\mathrm{MnO}$ & $0.01(0.00)$ & $0.01(0.00)$ & $0.01(0.00)$ & 0.01 & $0.01(0.00)$ \\
\hline $\mathrm{MgO}$ & $0.34(0.07)$ & $0.26(0.03)$ & $0.67(0.08)$ & 0.66 & $0.24(0.06)$ \\
\hline $\mathrm{CaO}$ & $0.17(0.02)$ & $0.13(0.03)$ & $0.39(0.46)$ & 40.70 & $0.06(0.02)$ \\
\hline $\mathrm{Na}_{2} \mathrm{O}$ & $3.22(0.56)$ & $2.14(0.60)$ & $0.22(0.15)$ & $\mathrm{Nd}$ & $1.03(0.75)$ \\
\hline $\mathrm{K}_{2} \mathrm{O}$ & $1.81(0.27)$ & $2.33(0.26)$ & $2.17(0.05)$ & 0.58 & $1.31(0.30)$ \\
\hline $\mathrm{P}_{2} \mathrm{O}_{5}$ & $0.11(0.04)$ & $0.19(0.03)$ & $0.14(0.06)$ & 0.18 & $0.07(0.03)$ \\
\hline LOI $(\%)$ & $3.60(0.26)$ & $5.40(1.01)$ & $8.20(1.32)$ & 34.30 & $5.24(0.88)$ \\
\hline $\mathrm{Ba}(\mathrm{ppm})$ & $461(120)$ & $625(42)$ & $401(67)$ & 95 & 304 (76) \\
\hline Co & $4(5)$ & $2(1)$ & $2(1)$ & 2 & $3(1)$ \\
\hline $\mathrm{Cr}$ & $76(24)$ & $59(5)$ & $73(13)$ & 66 & $46(9)$ \\
\hline $\mathrm{Hf}$ & $3(0)$ & $4(1)$ & $3(0)$ & $<0.1$ & $3(1)$ \\
\hline $\mathrm{La}$ & $19(3)$ & $36(2)$ & $13(3)$ & 6 & $14(2)$ \\
\hline $\mathrm{Nb}$ & $7(1)$ & $8(1)$ & $6(1)$ & 1 & $5(2)$ \\
\hline $\mathrm{Rb}$ & $60(11)$ & $72(7)$ & $91(13)$ & 30 & $48(10)$ \\
\hline $\mathrm{Sc}$ & $11(1)$ & $12(2)$ & $9(2)$ & 6 & $7(2)$ \\
\hline $\mathrm{Sr}$ & 547 (121) & 830 (144) & 193 (104) & 587 & 295 (144) \\
\hline $\mathrm{Th}$ & $7(1)$ & $8(1)$ & $5(2)$ & 2 & $5(2)$ \\
\hline $\mathrm{U}$ & $2(1)$ & $2(0)$ & $2(0)$ & 3 & $2(0)$ \\
\hline V & 80 (17) & 80 (14) & 79 (1) & 29 & $41(12)$ \\
\hline $\mathrm{Y}$ & $14(2)$ & $17(3)$ & $13(3)$ & 8 & $18(12)$ \\
\hline $\mathrm{Zn}$ & $23(20)$ & $15(3)$ & $50(20)$ & 36 & $25(12)$ \\
\hline $\mathrm{Zr}$ & $100(8)$ & $126(14)$ & $93(7)$ & 22 & $84(31)$ \\
\hline Total (\%) & $98.75(0.16)$ & $98.76(0.31)$ & $99.29(0.39)$ & 100.04 & 99.05 (0.22) \\
\hline CIA & $74(1)$ & 77 (3) & $81(4)$ & & $87(3)$ \\
\hline $\mathrm{Ba} / \mathrm{Sc}^{*}$ & $45(12)$ & $58(10)$ & $45(5)$ & 17 & $41(8)$ \\
\hline $\mathrm{La} / \mathrm{Sc}$ & $2(0)$ & $3(1)$ & $1(0)$ & 1 & $2(0)$ \\
\hline $\mathrm{Th} / \mathrm{Sc}$ & $1(0)$ & $1(0)$ & $1(0)$ & $<<1$ & $1(0)$ \\
\hline $\mathrm{Sr} / \mathrm{Y}$ & $41(3)$ & $52(14)$ & $17(7)$ & 73 & $26(17)$ \\
\hline $\mathrm{K}_{2} \mathrm{O} / \mathrm{Na}_{2} \mathrm{O}$ & $1(0)$ & $1(1)$ & $13(4)$ & NI & $2(1)$ \\
\hline
\end{tabular}

Detection limits: for oxides, $\pm 1 \%$; for trace elements (in ppm), Ba, 5; Co, 1; Cr, 1; Hf, 0.1; Nb, 0.08; Rb, 0.2; Sc, 0.5; Sr, 2; Th, 0.05; $\mathrm{U}, 0.01 ; \mathrm{V}, 1 ; \mathrm{Y}, 0.2 ; \mathrm{Zn}, 5 ; \mathrm{Zr}, 6$. 


\section{Conglomerate clast types}

Torehina conglomerates are polymictic (Fig. 5A), with a majority of subrounded to well rounded clasts. An exception occurs at locality A, where angular fractured clasts of similar composition as the underlying basement strata form a thin sandy breccia unconformably overlying the Moehau Formation (Fig. 4). Elsewhere, the typical Torehina pebble facies overlies a "cleaned" paleosurface, with no indication of a reworked or in situ regolith.

Both the TA and UA suites stand out visually in outcrop. TA specimens represent 70-80\% of visible clasts (Fig. 5A), and are very well indurated, generally fine grained, and display a dark (with finer grain size) to medium grey colour on fresh and weathered surfaces. Lithic and feldspar grains are conspicuously whitish to yellowish in colour. These clasts are mostly metamorphosed lithic wackes and arenites (Fig. 6A). UA clasts are medium to coarse grained (Fig. 5A), and are mostly lithic to quartz wackes and arenites. Uncommonly, granule conglomerate is present as well. Some clasts include fragments of coaly siltstone or possess in situ coal laminae; one of these latter examples also displays microfaults (Fig. 5B) that are truncated by the erosional margin of the clast, itself suggesting an inherited fabric from the source area. All UA clasts contain fragments of duncoloured kaolinitic siltstone that are fine to coarse in size. These fragments stain yellow, indicating the presence of potash feldspar. UA clasts display increased friability with increased grain size, and are light grey in colour on both weathered and fresh surfaces (Fig. 5A), but the coarser grained sandstones take on a salt-and-pepper colour due to dark-coloured metamorphic (micaceous) siltstone fragments.

There is considerable overlap and range in quartz and feldspar percentages between and within the UA and TA clast groups (Fig. 6B), but only a minor overlap exists with the specimens analysed from the Moehau Formation (Skinner 1972) and southern Waipapa Terrane (Fig. 6B) (Mortimer et al. 1997). The QFL distribution for Torehina clasts falls within Dickinson \& Suczek's (1979) "recycled orogen provenance" (Fig. 6B). In both UA and TA clast groupings, the relative mineral abundance is monomictic quartz > potash feldspar $(<16 \%)>>$ plagioclase (trace amount). Dusty weathering (=kaolinite) albite occurs locally in UA clasts. The detrital crystalline component of all clasts varies from angular to well rounded, with lithic fragments tending to be more rounded. Lithic fragments consist of volcanic, metasedimentary (muscovite-bearing siltstones), and detrital microcrystalline chert. This latter constituent is abundant in all clast types (Fig. 7A), and represents up to $20 \%$ of lithic grains in some TA clasts. However, chert also acts as a cement or as a relatively extensive replacement of matrix (Fig. 7B). Microveins of microcrystalline quartz are contiguous with such replacement fabric. (Samples with such veins and replacement chert were not included in geochemical analysis.) Crystalline fabrics of replacement and detrital chert are similar, suggesting that the latter represents recycling of the former.

Accessory constituents of UA and TA clasts include trace amounts of micas (muscovite, biotite) and rare heavy minerals. Chlorite was neither observed nor detected by XRD. Instead, kaolinite and illite are prominent constituents of the matrix in both clast types, especially in UA clasts. Sericite occurs in association with quartz microveins that crosscut some UA clasts, but otherwise is not significant. Other than the kaolinitebearing siltstones, yellow-weathering lithic fragments in both TA and UA clasts stain yellow with sodium cobaltinitrate, indicating the presence of potash feldspar.

Table 3 Mean and 95\% confidence interval (in brackets) values for non-normalised rare-earth element data, and selected ratios, associated with clast types (UA = uncertain source affinity; TA = basement terrane affinity) and three sediment groups from the Torehina Formation. Other information: number of samples $(n)$; subscript $\mathrm{N}$ indicates use of chondrite-normalised values following Taylor \& McLennan (1985). Ratios are rounded to nearest integer, with 95\% confidence intervals shown to nearest integer.

\begin{tabular}{|c|c|c|c|c|c|}
\hline & \multicolumn{2}{|c|}{ Clasts } & \multirow[b]{2}{*}{$\begin{array}{l}\text { Post-unconformity } \\
\qquad n=3\end{array}$} & \multicolumn{2}{|c|}{ Sediment } \\
\hline & $\begin{array}{c}\text { TA } \\
n=6\end{array}$ & $\begin{array}{c}\text { UA } \\
n=9\end{array}$ & & $\begin{array}{l}\text { Siltstone } \\
n=1\end{array}$ & $\begin{array}{c}\text { Lower sandstone } \\
\qquad n=9\end{array}$ \\
\hline $\mathrm{La}$ & $19.02(3.40)$ & $35.57(9.48)$ & $13.00(2.88)$ & 6.72 & $14.24(3.10)$ \\
\hline $\mathrm{Ce}$ & $40.02(5.84)$ & $74.19(16.91)$ & $19.79(5.78)$ & 9.9 & $28.97(8.19)$ \\
\hline $\operatorname{Pr}$ & $4.84(0.78)$ & $9.29(2.13)$ & $2.40(0.77)$ & 1.54 & $3.57(1.10)$ \\
\hline $\mathrm{Nd}$ & $18.39(3.38)$ & $36.38(8.03)$ & $8.18(2.02)$ & 6.27 & $13.39(5.02)$ \\
\hline $\mathrm{Sm}$ & $3.55(0.74)$ & $6.95(1.46)$ & $1.47(0.21)$ & 1.22 & $2.60(1.24)$ \\
\hline $\mathrm{Eu}$ & $0.89(0.20)$ & $1.65(0.29)$ & $0.38(0.05)$ & 0.3 & $0.62(0.28)$ \\
\hline Gd & $2.82(0.51)$ & $4.88(0.74)$ & $1.45(0.24)$ & 1.21 & $2.12(1.03)$ \\
\hline $\mathrm{Tb}$ & $0.41(0.07)$ & $0.64(0.11)$ & $0.25(0.04)$ & 0.18 & $0.33(0.15)$ \\
\hline Dy & $2.46(0.32)$ & $3.44(0.68)$ & $1.68(0.32)$ & 1.06 & $2.07(0.88)$ \\
\hline Ho & $0.50(0.06)$ & $0.65(0.15)$ & $0.42(0.09)$ & 0.22 & $0.44(0.18)$ \\
\hline $\mathrm{Er}$ & $1.48(0.14)$ & $1.88(0.43)$ & $1.29(0.25)$ & 0.59 & $1.31(0.52)$ \\
\hline $\mathrm{Tm}$ & $0.23(0.02)$ & $0.28(0.06)$ & $0.21(0.03)$ & 0.08 & $0.20(0.08)$ \\
\hline $\mathrm{Yb}$ & $1.57(0.14)$ & $1.88(0.41)$ & $1.39(0.29)$ & 0.53 & $1.41(0.52)$ \\
\hline $\mathrm{Lu}$ & $0.26(0.02)$ & $0.31(0.06)$ & $0.24(0.03)$ & 0.08 & $0.22(0.08)$ \\
\hline REE & $106(15)$ & $178(25)$ & $52(11)$ & 30 & $72(22)$ \\
\hline $\mathrm{La} / \mathrm{Yb}$ & $14(2)$ & $19(4)$ & $10(3)$ & 13 & $11(2)$ \\
\hline $\mathrm{La}_{\mathrm{N}} / \mathrm{Yb}_{\mathrm{N}}$ & $9(1)$ & $13(2)$ & 7 (2) & 9 & 7 (1) \\
\hline $\mathrm{Gd}_{\mathrm{N}} / \mathrm{Lu}_{\mathrm{N}}$ & $1(0)$ & $2(0)$ & $1(0)$ & 2 & $1(0)$ \\
\hline $\mathrm{Eu} / \mathrm{Eu}^{*}$ & $1(0)$ & $1(0)$ & $1(0)$ & 1 & $1(0)$ \\
\hline
\end{tabular}

Detection limits (in ppm): La, 0.2; Ce, 0.3; Pr, 0.03; Nd, 0.2; Sm, 0.03; Eu, 0.004; Gd, 0.03; Tb, 0.001; Dy, 0.01; Ho, 0.002; Er, 0.006; Tm, 0.005; Yb, 0.01; Lu, 0.001. 
Fig. 5 Conglomerate clasts. A, Cross-sectional view of clasts of uncertain source (UA) derivation (light in colour, see arrows) in conglomerate overlain by sandstone (S), with stratigraphic top to the right. The black line marks an irregular contact between sandstone and conglomerate. Scale bar $3 \mathrm{~cm}$. B, UA clast with thin coal laminae (arrow) and microfaults. Scale bar $3 \mathrm{~cm}$.
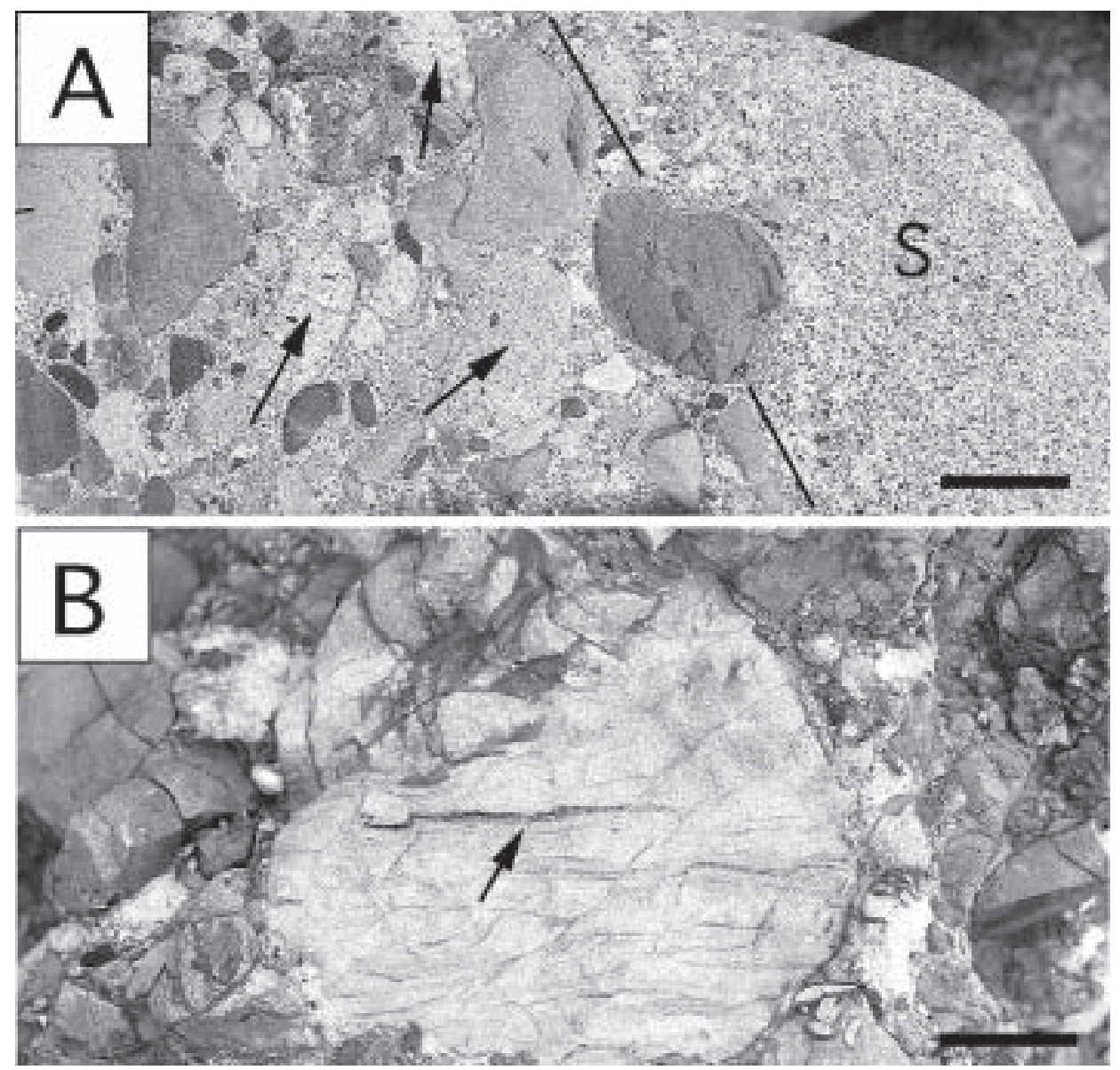

\section{Lower Torehina sandstones}

Sandstones range in composition from lithic wackes to lithic arenites and, uncommonly, quartz arenites (Fig. 5A, 6B). Notable is the appearance of minor $(<10 \%)$ unstrained polymesocrystalline quartz that is not observed in either clast groups or reported from local basement rocks. Kaolinite is also prominent as detrital matrix and as an alteration mineral. The texture and lithology of some sandstones interstratified with conglomerates are similar to UA clasts (Fig. 5A). This suggests mechanical disintegration of friable coarse-grained clasts during transport, and that the present friability of clasts is likely an inherited characteristic. It also suggests an outcrop source that was easily eroded.

\section{Post-unconformity sediment}

Clayey, sandy siltstone and fine-grained sandstone form a lithologic unit that overlies a prominent paleokarst surface within the Torehina Formation (Fig. 4, localities F and G). The sediment is non-calcareous, and contains <20\% very coarse silt and sand size silicate particles, with a relative mineral abundance of quartz > potash feldspar $>>$ plagioclase. These particles are subrounded to angular, and are similar in texture to the siliciclastic component of the underlying calcareous siltstone and silty microcrystalline limestone exposed at localities E and F (Fig. 4).

\section{GEOCHEMICAL ATTRIBUTES}

We use major and trace elements and their ratios from samples analysed during this study (Fig. 8-15; Tables 2, 3) to discriminate possible tectonic settings (e.g., Bhatia 1985; Roser \& Korsch 1986, 1988; McLennan et al. 1990) that formed possible source areas for the clasts. We then compare these inferred tectonic settings to those interpreted to have existed in New Zealand before and during deposition of Torehina sediments (e.g., Roser \& Korsch 1986; Mortimer 1995a,b; Mortimer et al. 1997).

\section{Evidence and extent of weathering}

The Chemical Index of Alteration (CIA; Nesbitt \& Young 1982) is a measure of the intensity of chemical weathering. It is based on the idea that plagioclase generally weathers at a faster rate than does potash feldspar. Weathering produces clay (e.g., kaolinite, illite) that concentrates alumina and silica whereas calcium, sodium, and potassium are removed. For the TA and UA clast groups, chemical weathering is indicated by kaolinitic alteration of feldspars. Given the obvious detrital kaolinite fraction in UA clasts, the CIA values also represent mixtures of weathered and non- (or least) weathered material.

Our data (Fig. 8) are shown relative to trends calculated and observed for weathering of granodiorite (Nesbitt \& Young 1989) and rocks representative of the Torlesse Terrane 


\section{A}

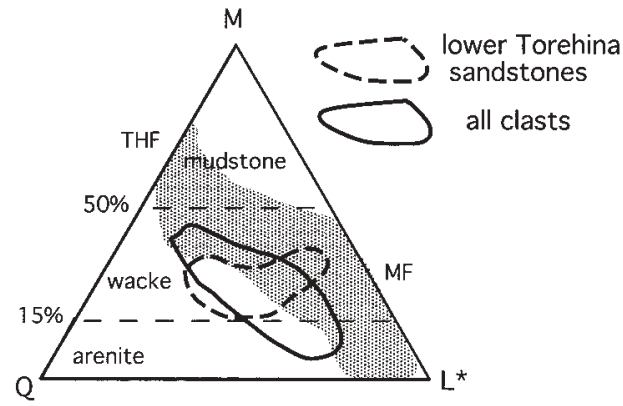

B

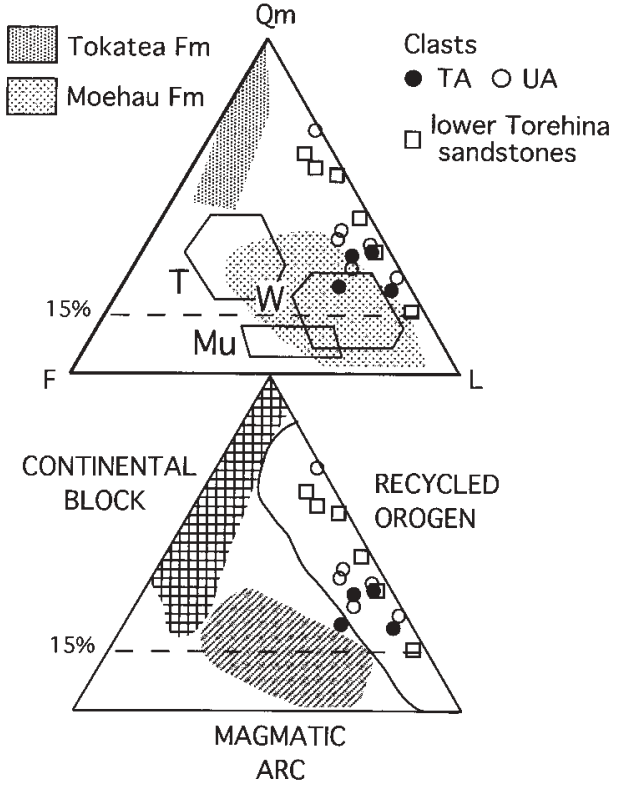

Fig. 6 Textural and mineral composition of clasts and sediment. A, Lithology of UA and TA clasts (see text for definition) and lower Torehina sandstones, according to Dott's (1964) classification, is shown relative to the distribution (shaded) known for strata of the Manaia Hill Group, with endmember compositions of the local Moehau Formation (MF) and Tokatea Hill Formation (THF) from Skinner (1972). M, Q, and $\mathrm{L}^{*}$ refer to matrix, quartz, and lithic + feldspar grains, respectively. B, Distribution of clasts and sediment according to ternary plot of Qm (monocrystalline quartz), F (feldspar), and L (lithic) percentages. For reference: Moehau and Tokatea Formations (Manaia Hill Group; Skinner 1972); and southern Waipapa (W), Murihiku (Mu), and Torlesse (T) Terranes (Mortimer et al. 1997). The lower triangle shows compositional distributions for general tectonic terranes according to Dickinson \& Suczek (1979).

(Roser \& Korsch 1999). An increase in weathering is defined, first by a path directed toward the $\mathrm{Al}_{2} \mathrm{O}_{3}-\mathrm{K}_{2} \mathrm{O}$ tie line, then toward the $\mathrm{Al}_{2} \mathrm{O}_{2}$ endmember (Nesbitt \& Young 1989). As shown in Fig. 8, UA clasts fall along the granodiorite trend. They contain detrital kaolinite, and their CIA values support weathering of a granitic source. Torehina sandstones represent an advanced state of chemical weathering, whereas both TA and UA clasts, with CIA values of 70-85, record moderate to advanced stages of weathering. The same interpretation is applied to post-unconformity sediment. The small population of TA clasts and sample of postunconformity sediment might define a separate trend oblique to the IWL line, one that is oriented to merge with the Torlesse trend at the illite endmember (Fig. 8).
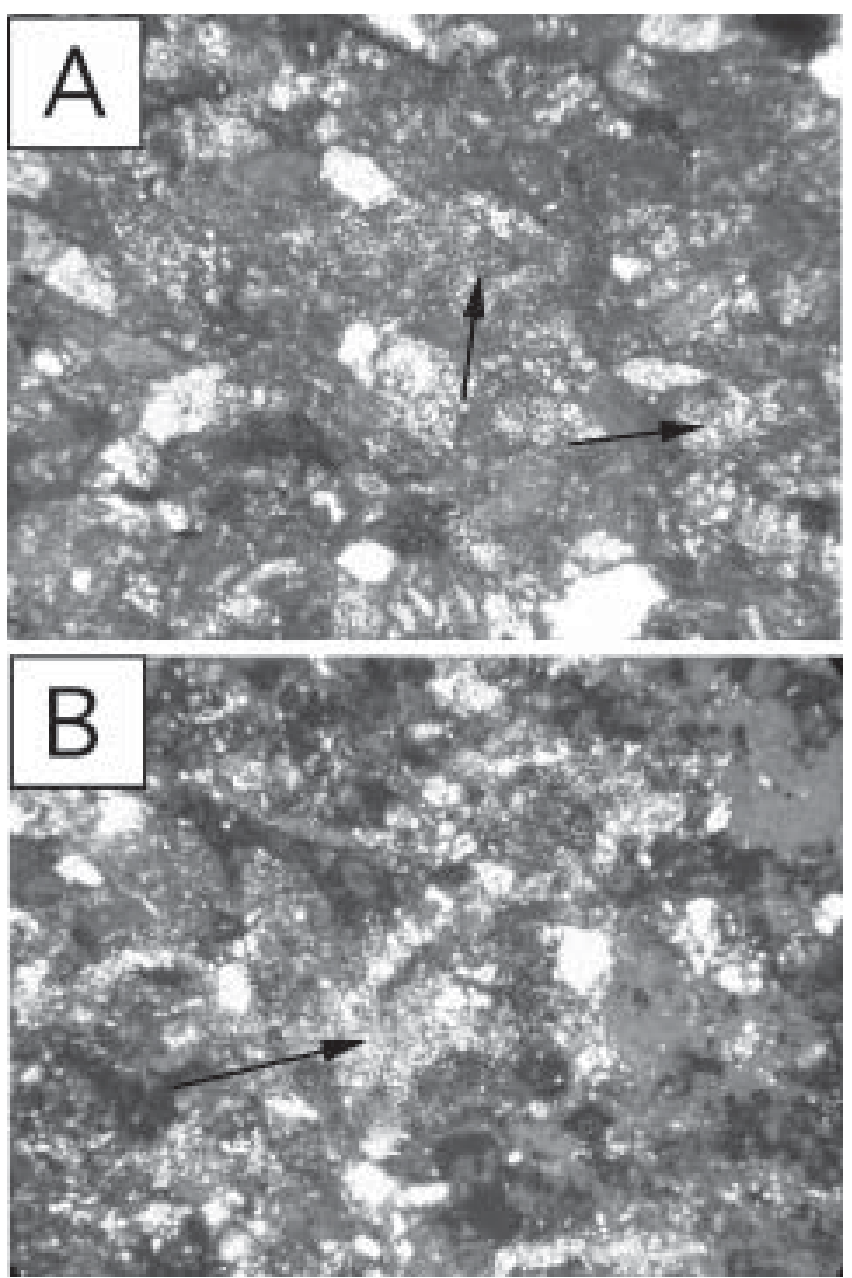

Fig. 7 A, Detrital chert (arrows) in clast that has a lithological affinity to metasedimentary basement rocks. Replacement matrix chert is located left of the uppermost arrow. Polarised light, scale bar $500 \mu \mathrm{m}$. B. Chert replacing matrix of a similar basement-derived clast. Polarised light, scale bar $500 \mu \mathrm{m}$.

\section{Geochemical indicators of tectonic provenance}

\section{General tectonic setting}

The ratio $\mathrm{K}_{2} \mathrm{O} / \mathrm{Na}_{2} \mathrm{O}$ versus $\mathrm{SiO}_{2} \%$ was used by Roser \& Korsch (1986) to characterise three tectonic settings of continental margin sandstones (Fig. 9). The majority of Torehina clasts lie within the active continental margin (ACM) domain, and overlap the field for Torlesse sandstones from South Island (Roser \& Korsch 1986). Some TA and UA clasts fall within the uppermost $\mathrm{SiO}_{2} \%$ range for Manaia Hill Group, a range that straddles the ACM and volcanic arc (ARC) domain boundaries (Fig. 9). Such elevated $\mathrm{SiO}_{2} \%$ for the majority of Torehina clasts can be accounted for by an overall greater percentage of detrital chert (Table 1).

Two subsets of the UA clasts are identified. One group has a similar distribution as the TA cluster, falling within the $\mathrm{ACM}$ domain. A second group has higher $\mathrm{K}_{2} \mathrm{O} / \mathrm{Na}_{2} \mathrm{O}$ ratios, and falls within the Ordovician Greenland Group field (Roser \& Korsch 1986), which straddles the passive margin (PM) and ACM domain boundary (Fig. 9). Increased $\mathrm{K}_{2} \mathrm{O} / \mathrm{Na}_{2} \mathrm{O}$ ratios are due to still-present potash feldspathic matrix in these clasts as indicated by staining. Lower Torehina 


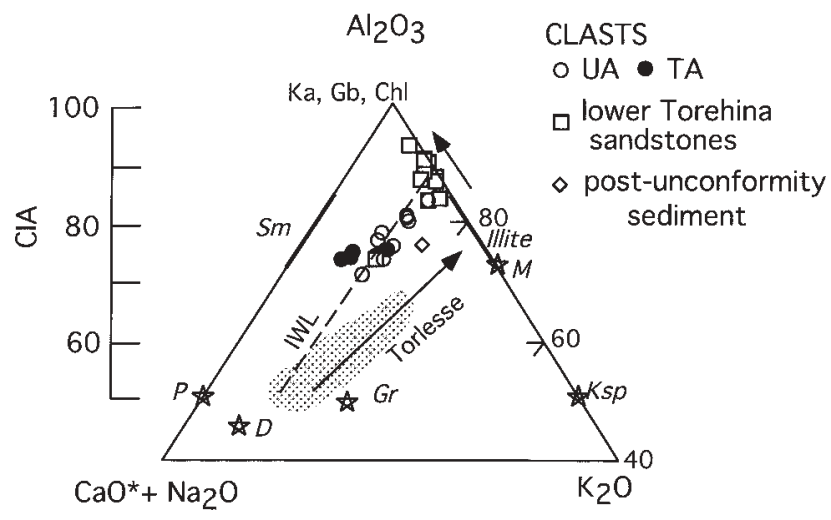

Fig. 8 Distribution of Torehina clast types (see text for definition) on the basis of the chemical index of alteration (CIA). UA clasts plot along the ideal weathering line (IWL) for granodiorites (Nesbitt \& Young 1989; Roser \& Korsch 1999) whereas TA clasts may define a trend that would merge with the Torlesse Terrane population (from Roser \& Korsch 1999) at the illite endmember. Distribution plot is based on constituent molar values. Letter symbols: Ka, kaolinite; Gb, gibbsite; Chl, chlorite; Sm, smectite; M, muscovite; Ksp, potash feldspar; P, plagioclase; D, diorite; Gr, granite. $\mathrm{CaO}^{*}$ indicates correction for apatite and thus includes $\mathrm{CaO}$ contained in the silicate fraction.

sandstones, due to their elevated quartz content and a similar feldspathic-bearing matrix, and post-unconformity sediment plot well within the PM field (Fig. 9).

Bhatia \& Crook (1986) proposed chemical criteria for discriminating tectonic domains. Our data plot almost entirely within their continental island arc domain (Fig. 10), a domain that is comparable to the ACM terrane of Roser \& Korsch (1986) because these latter authors included sediment derived from deeply dissected continental magmatic arcs (p. 638). Most Torehina clasts fall within the field defined for dissected (or recycled) orogenic belts (Fig. 10).

\section{Felsic versus volcanogenic sources}

Using discriminant analysis, Roser \& Korsch (1989) defined both mafic and felsic fields based on the chemical characteristics of Mesozoic terranes in New Zealand. Torehina clasts plot within their felsic field, and overlap the distribution for Torlesse rocks (Fig. 11). Torehina sandstones and siltstones lie within the quartzose field, a result that suggests greater reworking and concentration of less labile components.

There is additional evidence that sediment forming the clasts was derived from felsic sources. First, barium values in UA clasts are more elevated (>550 ppm; Table 2), and closer to an expected granite endmember (>700 ppm), than values displayed by TA clasts. In fact, the latter values are more similar to a volcanogenic endmember (400 ppm; Cullers et al. 1988). Second, Bhatia \& Crook's (1986) measure of $\mathrm{Ti} / \mathrm{Zr}$ versus $\mathrm{La} / \mathrm{Sc}$ to discriminate between oceanic island arc deposits ( $\mathrm{Ti} / \mathrm{Zr}>40)$ and continental margin deposits (Ti/ $\mathrm{Zr}<25$ ) shows that most TA clasts have $\mathrm{Ti} / \mathrm{Zr}$ values greater than 20. This may indicate a greater affinity to volcanogenic sources such as the Caples-Waipapa and Murihiku Terranes (Fig. 12). In addition, the majority of UA clasts have La/Sc values greater than TA clasts, and more similar to Torlesse rocks (Fig. 12). However, there is obvious overlap. This is

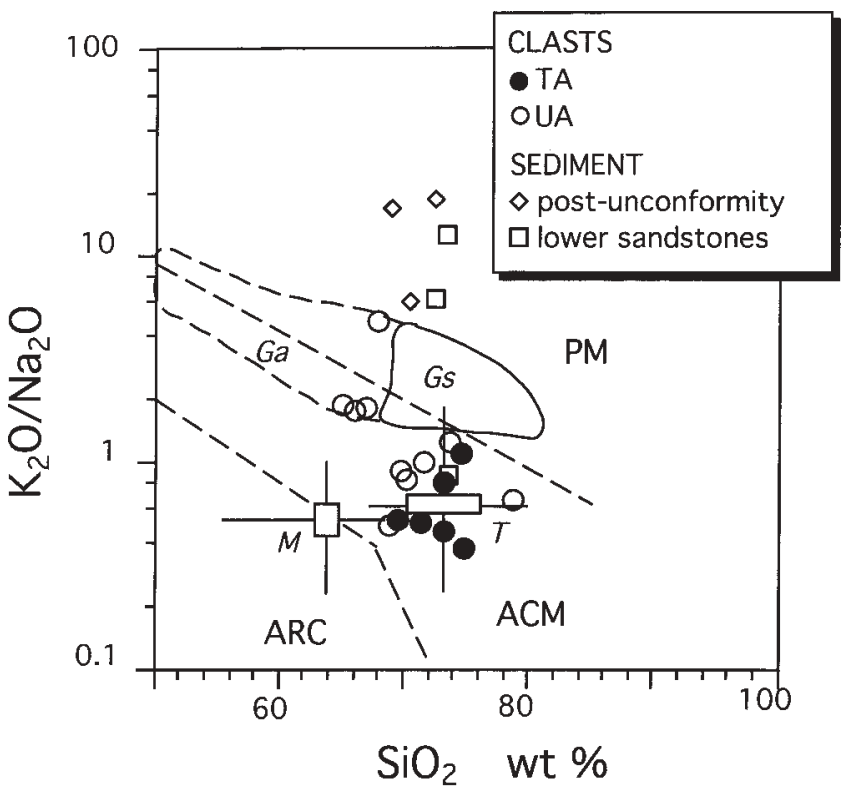

Fig. 9 Distribution of Torehina clast types (see text for definition) relative to distribution of continental margin sandstones by tectonic setting on the basis of $\mathrm{K}_{2} \mathrm{O} / \mathrm{Na}_{2} \mathrm{O}$ versus $\mathrm{SiO}_{2}$ wt\% (Roser \& Korsch 1986): ARC, volcanic arc; ACM, active continental margin; PM, passive margin. The fields shown for Gs and Ga refer to sandstone and argillaceous suites, respectively, of the Ordovician Greenland Group (South Island; Roser \& Korsch 1986). Average (box) and range (crosslines) of variation is shown for Manaia Hill Group (M) and Torlesse (T) rocks (from Roser \& Korsch 1986; Mortimer 1995b).

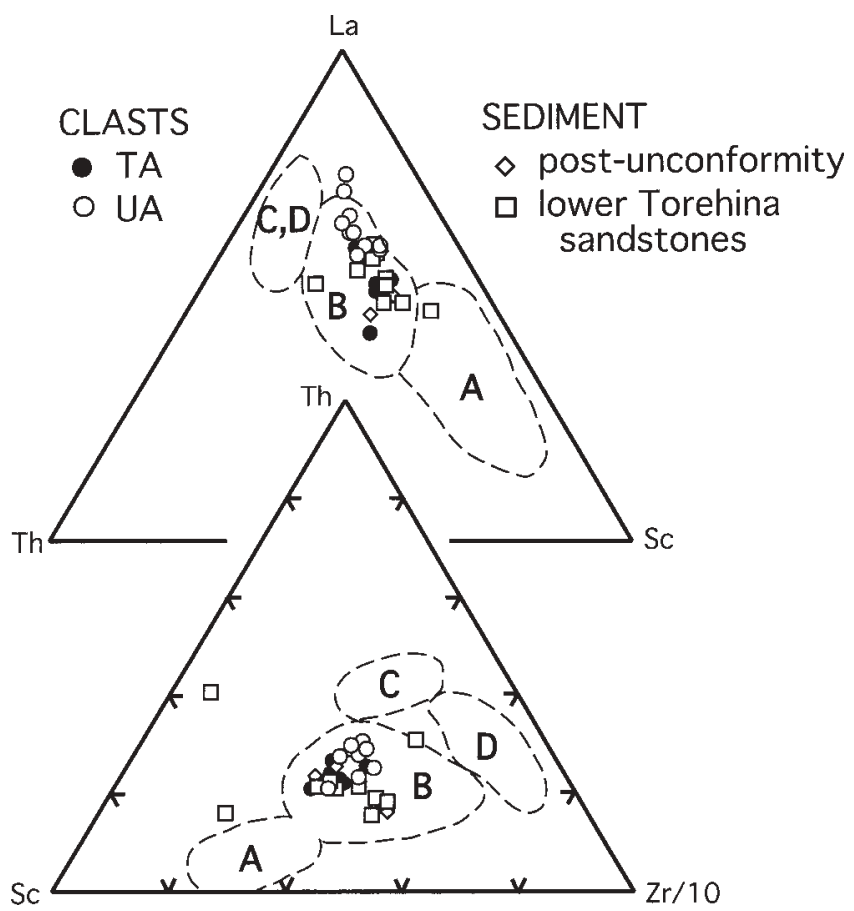

Fig. 10 Distribution of Torehina clast types (see text for definition) and sediment relative to $\mathrm{La}, \mathrm{Th}, \mathrm{Sc}$, and $\mathrm{Zr} / 10$ ratios, and distribution of general tectonic fields for sandstones defined by Bhatia \& Crook (1986): A, oceanic island arc; B, continental island arc; $C$, active continental margin; $D$, passive margin. See text for details. 

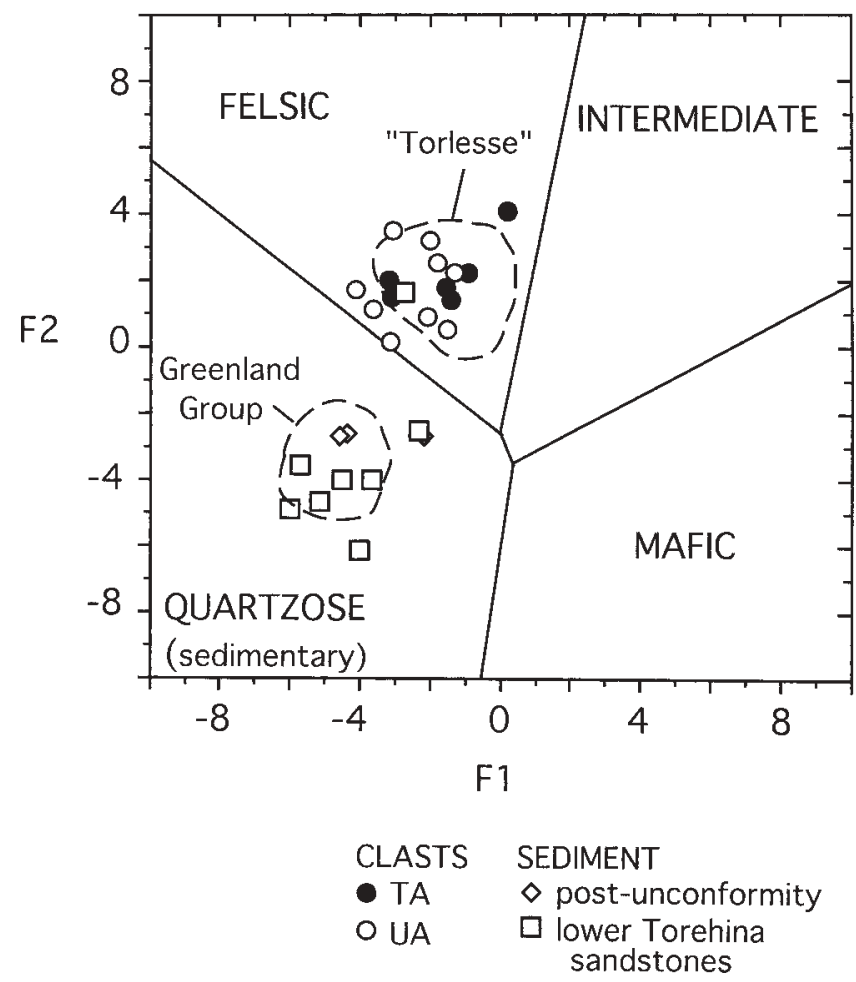

Fig. 11 Distribution of Torehina clast types (see text for definition) and sediment relative to provenance fields defined by Roser \& Korsch (1988) on the basis of discriminant function (F1 and F2) analysis.

also noted from a plot of Th/Sc versus Zr/Sc (Fig. 13) (Roser $\&$ Korsch 1999) wherein the fields for TA and UA clasts fall within an overlap of Torlesse and more volcanogenic terrane rocks fields.

These differences imply a greater felsic component to UA clasts. In fact, Ti/Zr values of UA and TA clasts are similar to some values known from the Cretaceous Separation Point Batholith (Fig. 12) (Muir et al. 1995). This intrusive complex occurs along the western side of South Island, within a continental margin arc setting that lay adjacent to, but west of, the Murihiku volcanogenic terrane (Mortimer 1995b). Similar geochemical signatures have been documented by Mortimer et al. (1997) from rocks that form the basement to Wanganui Basin, southwest North Island (Fig. 1). These granitic sources are notable for elevated Sr concentrations (Muir et al. 1995; Mortimer et al. 1997). We find similar elevated Sr concentrations (Fig. 14), but our clasts differ from the Separation Point Batholith with respect to other geochemical measures. Nonetheless, our comparison underscores the possible contribution of lithic fragments and/ or detrital minerals within these clasts from a Sr-rich felsic source.

\section{REE patterns}

A summary of rare-earth element data is presented in Table 3. Chondrite-normalised (Taylor \& McLennan 1985) patterns for clasts and sediment are displayed in Fig. 15A-E. UA and TA groups overlap and are tightly clustered (Fig. 15A,C). Both groups show strong light rare-earth element (LREE) enrichment $\left(\mathrm{La}_{N} / \mathrm{Y}_{\mathrm{N}}>9\right)$, with UA clasts having a greater ratio (c. 13; Table 3 ). Both groups display a minor Eu anomaly

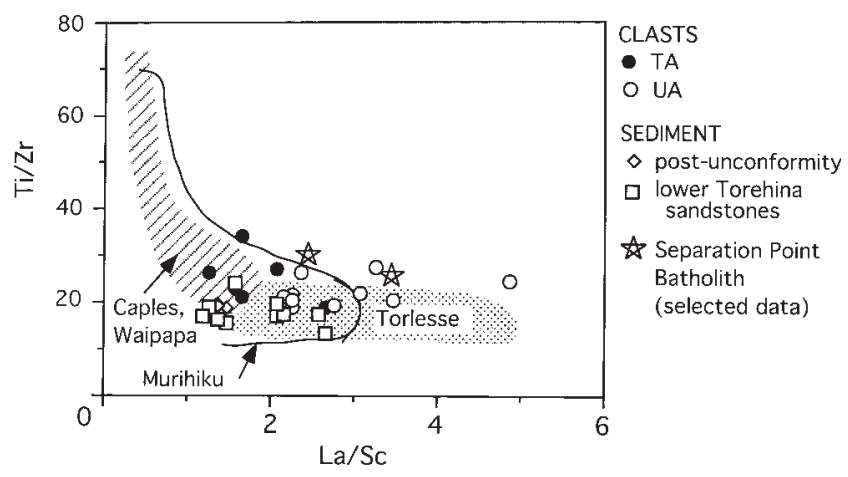

Fig. 12 Distribution of Torehina clast types (see text for definition) and sediment in relation to $\mathrm{Ti} / \mathrm{Zr}$ versus $\mathrm{La} / \mathrm{Sc}$. Also shown are distribution fields for some New Zealand terranes (Mortimer et al. 1997), and selected data from Separation Point Batholith (Muir et al. 1995). See text for details.

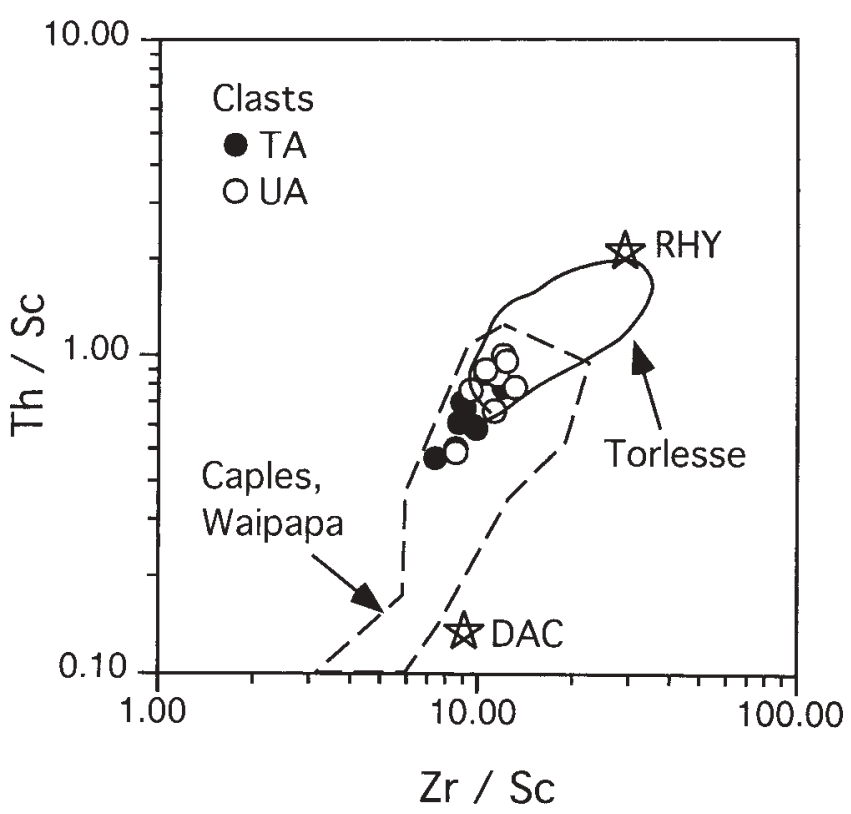

Fig. 13 Distribution of Torehina clast types (see text for definition) and sediment relative to $\mathrm{Th} / \mathrm{Sc}$ versus $\mathrm{Zr} / \mathrm{Sc}$, along with fields for some tectonic terranes in New Zealand, and endmember intersections for rhyolite (RHY) and dacite (DAC) (Roser \& Korsch 1999). See text for details.

$\left(\mathrm{Eu} / \mathrm{Eu}^{*}=0.85,0.87\right.$; Table 3$)$, and similar flat to slightly increasing trends for the heavy rare-earth elements (HREE) (Fig. 15A,C). A sample of the sandy matrix (NZ-4) in the basal Torehina conglomerate at locality D reveals higher HREE values than the clast groups (Fig. 15D). This might reflect a component of heavy mineral concentration, although none is visually obvious. Lower Torehina sandstones show more varied change in REE patterns (Fig. 15B), but possess similar LREE enrichment and HREE trends as the clasts. Post-unconformity sediment is compositionally indistinguishable from lower Torehina sandstones (Fig. 15E).

There is, overall, a negative shift in normalised REE abundances among the various groups; namely, UA clasts > TA clasts $>$ lower Torehina sandstones $=$ post-unconformity sediment $>$ calcareous siltstone (Fig. 15). The calcareous 

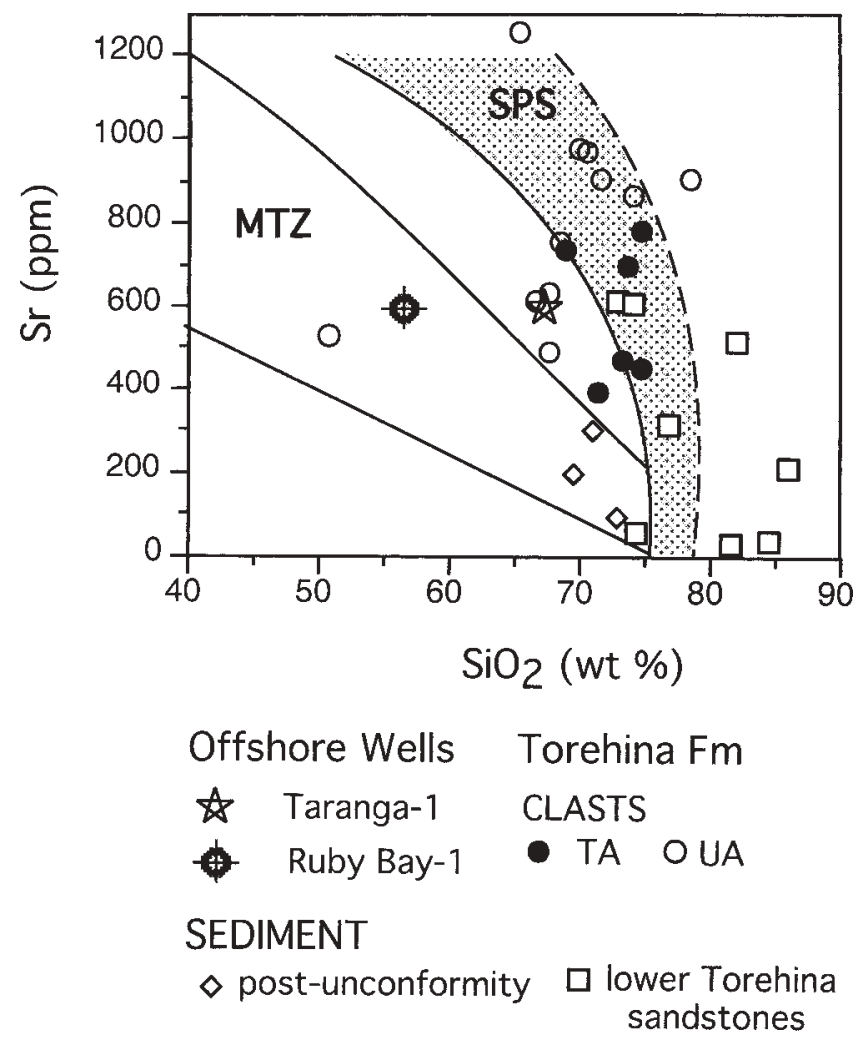

Fig. 14 Distribution of Torehina clast types (see text for definition) and sediment in relation to $\mathrm{Sr}$ versus $\mathrm{SiO}_{2}$ wt\%. Also shown are fields for Separation Point Batholith (SPS; Muir et al. 1995) and the Median Tectonic Zone (MTZ; Mortimer et al. 1997), as well as selected well data from Wanganui Basin (Mortimer et al. 1997).

siltstone sample (C5-B) from locality D (Fig. 4) has the lowest REE concentration (Fig. 15D) of all samples, illustrating likely dilution by carbonate. This sample contains a relatively strong negative Ce anomaly not found in any of our non-calcareous samples.

REE patterns for the TA group are indistinguishable from those defined for continental arc turbidites (McLennan et al. 1990), whereas UA patterns are displaced to slightly higher REE values (Fig. 15D,F). This difference might arise from mineral dilution effects. REE patterns for TA and UA clasts are similar to those for sediment derived from granitoid sources (Cullers et al. 1988), but dissimilar to those documented for the Cretaceous Separation Point Batholith, which displays strong HREE depletion (Muir et al. 1995). Available REE patterns for Torlesse and Murihiku Terrane rocks (Fig. 15F) (Bradshaw 1994) reveal a similar geometry to the Torehina clast trends, but with a pronounced Eu* anomaly.

\section{DISCUSSION}

Petrography and geochemistry of clasts from conglomerates within the lower Torehina Formation identify several sources that contributed to the basin-fill succession. Surprisingly, few clasts appear to have a petrology similar to local Manaia Hill Group strata (Table 1, Fig. 6B, 9).

CIA values for all our clasts record mixtures of variably weathered materials (Fig. 8). Due to humidity and rainfall in the North Island region, many outcrops in our study area illustrate impact of postdepositional weathering, which produces a well-defined penetrative, fabric-destructive alteration extending down from the soil-rock interface. The conglomerate facies of the Torehina Formation contains no pronounced break in sedimentation, and outcrops sampled do not contain such a penetrative alteration zone. The lithologic similarity between some UA clasts and lower Torehina sandstones, and fragility of the latter, suggests that mineralogy and fragility of these clasts reflect characteristics indicative of the source area. Absence of any obvious prolonged exposure of lower Torehina sediments during deposition implies little impact of weathering after deposition. Yet, the presence of some partially kaolinised feldspar grains suggests that a second generation of weathering, either within the source area or following clast deposition, did occur. We do not believe, however, that this obscures use of geochemical indicators to define possible source areas.

Thus, UA clasts, and especially friable coarse-grained clasts that possess coal-laminae or coal fragments, represent an exotic sedimentary facies compared to the local and regional deep-water facies of the Mesozoic basement terranes of North Island. The abundance of detrital kaolinite-bearing lithic fragments and quartz within UA clasts, along with a CIA trend that matches ideal and observed granodioritic weathering (Fig. 8), indicates mechanical and advanced chemical weathering of a continental felsic-dominated source area. The roundness and friability of coarse-grained UA clasts suggest that transport distance was necessarily limited. The occurrence of these clasts throughout the lower part of the Torehina Formation, together with REE data that reveal a geochemical similarity between younger sandstones and these clasts (Fig. 15B,E), suggests that the source continued to supply sediment through to late Oligocene time.

Coal-bearing UA clasts identify a likely non-marine or marginal marine source. Furthermore, excluding silcretes, cementation of siliciclastic sediment commonly attends burial (Surdam et al. 1989). Thus, the appearance of coal-bearing UA clasts in Torehina conglomerates identifies a likely paragenetic history of source sediment burial, its cementation, then relative uplift and erosion. Coalification (either at source or in situ) also requires such a history. This requisite pattern does not fit the known early Tertiary geologic history of North Island (King et al. 1999), and a pre-Tertiary history is likely.

\section{A Cretaceous source}

There are two possible sources for coal-bearing UA clasts. First, coal and organic-bearing facies are reported from metamorphosed facies of the Torlesse Terrane (Baker \& Staveley Parker 1989) and better developed in the Murihiku Terrane, part of the Late Jurassic Huriwai braidplain delta (Ballance 1988). But the described texture and metamorphic overprint do not appear to match characteristics of UA clasts, especially the coarser grained specimens. Alternatively, UA clasts were derived from erosion of a Late Cretaceous "suprabasement" sedimentary cover, which had accumulated from erosion of metamorphic basement terranes following their amalgamation, deformation, and uplift.

It is tectonically and lithologically reasonable to consider the source(s) of UA clasts to be of Late Cretaceous age. Along the western margin of South Island and in the subsurface strata off western North Island (Laird 1993; King 

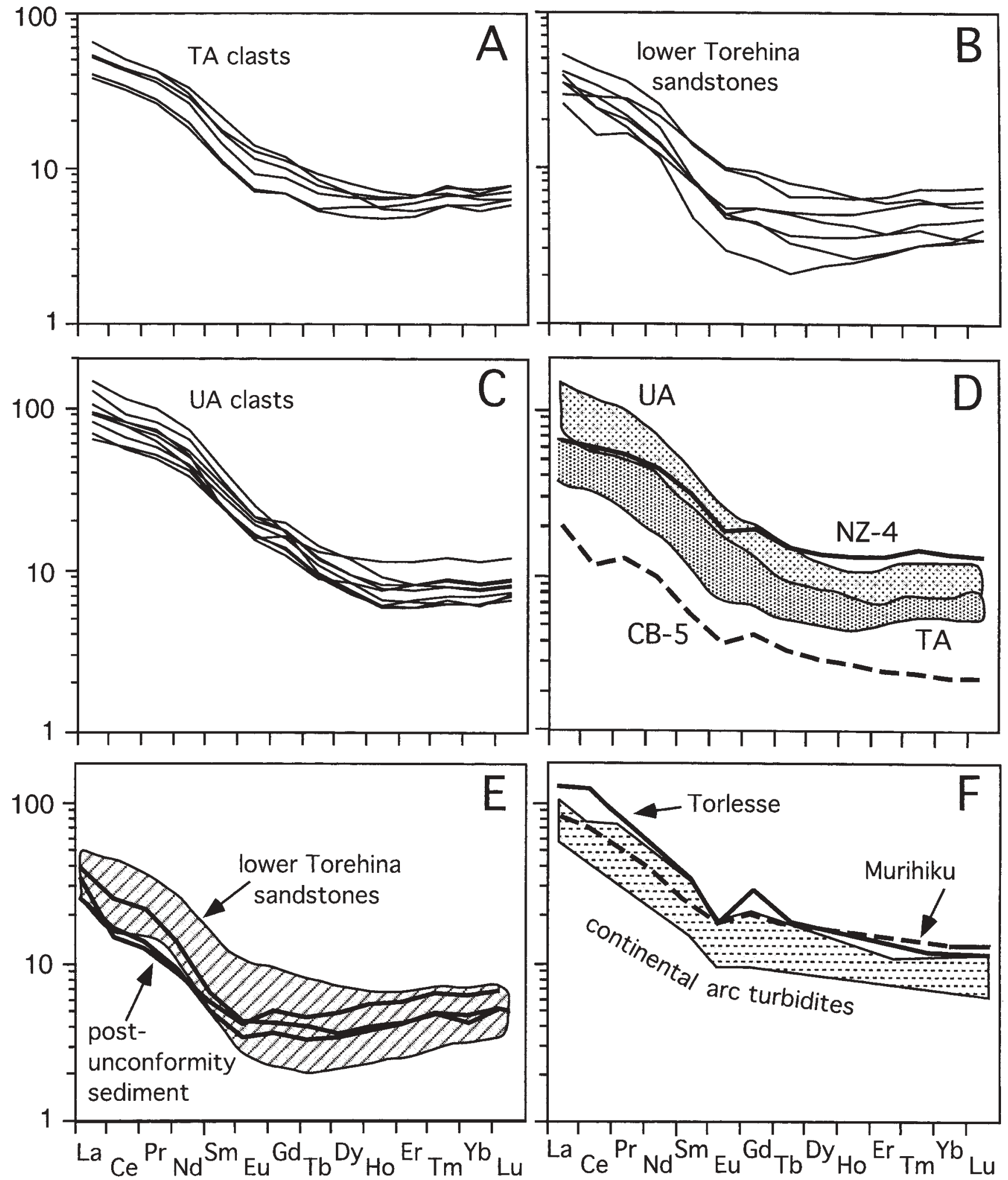

Fig. 15 Details of chrondrite-normalised (Taylor \& McLennan 1985) rare-earth element (REE) patterns for Torehina clasts and sediment. A-C, Individual patterns for clasts of interpreted basement terrane affinity (TA), lower Torehina sandstones, and clasts of unknown lithological affinity (UA), respectively. D, Comparison of fields for UA and TA clasts, and individual patterns for sandy matrix of conglomerate (NZ-4, locality D) and calcareous siltstone (CB-5, locality E). E, Comparison of the field for lower Torehina sandstones (Fig. 15B) and post-unconformity sediment. F, Comparison of the signature for continental arc turbidites (McLennan et al. 1990) relative to available data for the Torlesse and Murihiku Terranes (Bradshaw 1994). See text for details. 
et al. 1999), Upper Cretaceous non-marine coal measures accumulated rapidly in half-grabens in the post-Rangitata orogenic period. Along the eastern margin of North Island, marine sandstones and siltstones of the Upper Cretaceous (Teratan) Raukumara Series overlie Torlesse basement. At least one unit contains "shiny coal fragments, presumably eroded from coal measures [farther] to the east" (Kingma \& Speden 1978, p. 374). Kamp \& Liddell (2000) have proposed a thick wedge of Cretaceous strata in the Kawhia Syncline region, western North Island (Fig. 1), to explain thermometry estimates for deep $(3 \mathrm{~km})$ burial of older strata. These authors speculated that sedimentation and burial continued into the Late Cretaceous (c. $85 \pm 10 \mathrm{Ma}$ ), followed by uplift and denudation. Thus, by the beginning of the Oligocene, continuing erosion of such a source may have allowed transport of sediment into the Torehina depositional basin.

However, by allowing for pre-Neogene terrane reconstruction (Black 1994), current patterns of Cretaceous coal-bearing sandstones identify sources that seem today much too distant $(>50 \mathrm{~km})$ to easily accommodate derivation of UA clasts from a proximal, easily eroded source. When compared to Kamp \& Liddell's (2000) work, however, we can envisage a regional cover of coal-bearing sandstones across North Island during the Late Cretaceous and early Tertiary. However, it is also possible that UA clasts have been reworked from a local Cretaceous basin now obscured by post-Cretaceous uplift and erosion. On the basis of reworked dinoflagellates in Miocene sediment, for example, Skinner (1993) suggested that a late Cretaceous-Eocene basin once existed in the Coromandel region. We cannot be more precise in defining either location or age of a sediment source for UA clasts, but their exotic petrofacies demonstrates a more complex history of post-Early Cretaceous basin development in the Coromandel region than revealed by the angular unconformity separating Torehina and Manaia Hill Group strata.

\section{Mesozoic terrane sources}

TA clasts also differ lithologically from local Manaia Hill Group rocks (Table 1, Fig. 6), although there is overlap in some geochemical signatures (Fig. 8-15). Does this reflect a simply greater petrologic variation of local basement lithologies than previously recognised? The smoothed paleoerosional surface (with one site as exception) that caps basement rocks in our study area, and the indurated nature of local basement metamorphosed sandstones and argillites, seemingly offer little likelihood for local derivation of TA clasts. Instead, clast induration and extent of roundness may reflect a lengthy transport history.

Geochemically, the greater felsic composition of TA clasts when compared to the Moehau Formation (Table 1), and the lesser quartz content than known for the Tokatea Formation, also illustrates a reduced likelihood for local derivation. Other compositional indicators suggest that sediment comprising the majority of TA clasts was derived from dissection of a continental magmatic arc, mixed with input from felsic and volcanogenic sources (Fig. 6B, 9-12).

There is equivocal evidence for paleo-transport directions of TA clasts. They were derived either from a northwestern (or western) to northern direction or southeastern to southern direction (Dix \& Nelson in press). If TA clasts were derived from a western-to-northwestern source, plate reconstruction (Black 1994; Mortimer et al. 1995a) indicates a west-to-east arrangement of decreasing volcanogenic terranes (the
Murihiku to Caples-Waipapa Terranes). Our geochemical data illustrate that such source derivation is reasonable (Fig. 1214). The Waipapa Terrane of North Island is itself a complex interleaving of subterranes and facies previously identified as part of the Torlesse Terrane (Black 1994; Mortimer 1995b), with sediment derived from dissection of pre-existing magmatic arc strata. Transport of sediment across this basement before and during Oligocene deposition would easily mix volcanogenic, siliceous, and felsic sources.

If clasts were derived from a southerly direction, possible sources include Waipapa and Torlesse rocks. Indeed, from east and south of Coromandel Peninsula, potential metamorphosed basement sources reveal increased availability of quartzofeldspathic material of granodioritic bulk composition (Roser \& Korsch 1999), as well as a greater variation in abundance of chert and volcanic detritus (Skinner 1978; Kear 1992; Mortimer 1995b).

\section{CONCLUSIONS}

Petrography and geochemistry of clasts contained in basal conglomerates of the Torehina Formation indicate the presence of two distinctive clast populations. One type, representing 20-30\% of all clasts, was derived from a coalbearing, marginal to non-marine source containing sediment derived from advanced weathering of a granitic terrane. Such a source best fits Late Cretaceous deposits on North Island. Friability of these clasts requires a proximal source, which demands a once greater paleogeographic distribution of Cretaceous strata than is now present.

The second, and larger (70-80\%), group of clasts reflects a mixture of lithologies typical of Mesozoic metasedimentary basement terranes. An elevated percentage of detrital chert, and geochemical indicators, points to more felsic and quartzrich sources compared to local (Manaia Hill Group) basement rocks. In contrast, textural and geochemical evidence suggests that clasts were derived from distal sources, during dissection of either several terranes that define a continental arc or from one terrane of variable composition. The Waipapa and Torlesse Terranes are likely the principal sources, but some clasts have geochemical signatures similar to the more westerly, volcanogenic Caples and Murihiku Terranes.

\section{ACKNOWLEDGMENTS}

Fieldwork was carried out while the first author was on sabbatical leave at University of Waikato (Hamilton, New Zealand). GRD thanks P. Fuller for field assistance; the Department of Earth Sciences, University of Waikato, for logistical support; and the Natural Sciences and Engineering Research Council (NSERC), Canada, for ongoing financial support. Both authors thank David Kear, David Skinner, and Phil Moore for discussions on Coromandel geology. Journal reviewers G. Girty and D. Skinner are thanked for their detailed comments and suggestions.

\section{REFERENCES}

Baker, C. K.; Staveley Parker, R. J. 1989: Coalification and metamorphism in Torlesse Supergroup rocks, North Island. New Zealand Journal of Geology and Geophysics 32: 429-435.

Ballance, P. F. 1988: The Huriwai braidplain delta of New Zealand: a late Jurassic, coarse-grained, volcanic-fed depositional system in a Gondwana forearc basin. In: Nemec, W.; Steel, R. J. ed. Fan deltas: sedimentology and tectonic settings. Blackie. Pp. 457-471. 
Bhatia, M. R. 1985: Rare earth element geochemistry of Australian Paleozoic graywackes and mudrocks: provenance and tectonic control. Sedimentary Geology 45: 97-113.

Bhatia, M. R.; Crook, K. A. W. 1986: Trace element characteristics of graywackes and tectonic setting discrimination of sedimentary basins. Contributions to Mineralogy and Petrology 92: 181-193.

Black, P. M. 1994: The "Waipapa Terrane", North Island, New Zealand: subdivision and correlation. Geoscience Reports of Shizuoka University 20: 55-62.

Bradshaw, J. D. 1994: Brook Street and Murihiku terranes of New Zealand in the context of a mobile South Pacific Gondwana margin. Journal of South American Earth Sciences 7: 325332.

Cullers, R. L.; Basu, A.; Suttner, L. J. 1988: Geochemical signature of provenance in sand-size material in soils and stream sediments near the Tobacco Root Batholith, Montana, USA. Chemical Geology 70: 335-348.

Dickinson, W. R.; Suczek, C. A. 1979: Plate tectonics and sandstone compositions. American Association of Petroleum Geologists Bulletin 63: 2164-2182.

Dix, G. R.; Nelson, C. S. in press: The role of tectonism in sequence development and facies distribution of Upper Oligocene cool-water carbonates: Coromandel Peninsula, New Zealand. Sedimentology.

Dott, R. H. Jr 1964: Wacke, graywacke and matrix—what approach to immature sandstone classification. Journal of Sedimentary Petrology 34: 625-632.

Hayward, B. W.; Moore, P. R.; Gibson, G. W. 1990: How warm was the Late Oligocene? Coconuts, reef corals and larger foraminifera. Geological Society of New Zealand Newsletter 90: 39-41.

Hochstein, M. P.; Nixon, I. M. 1979: Geophysical study of the Hauraki Depression, North Island, New Zealand. New Zealand Journal of Geology and Geophysics 22: 1-19.

Hutchinson, C. S. 1974: Laboratory handbook of petrographic techniques. New York, Wiley and Sons.

Isaac, M. J.; Herzer, R. H.; Brook, F. J.; Hayward, B. W. 1994: Cretaceous and Cenozoic sedimentary basins of Northland, New Zealand. Institute of Geological \& Nuclear Sciences Monograph 8. Lower Hutt, Institute of Geological \& Nuclear Sciences Ltd. 203 p.

Kamp, P. J. J.; Liddell, I. L. 2000: Thermochronology of northern Murihiku Terrane, New Zealand, derived from apatite FT analysis. Journal of the Geological Society of London 157: 345-354.

Kear, D. 1955: Mesozoic and lower Tertiary stratigraphy and limestone deposits, Torehina, Coromandel. New Zealand Journal of Science and Technology 37: 106-114.

Kear, D. 1992: Reflections on major North Island basement rock assemblages and on megafaults. Journal of the Royal Society of New Zealand 23: 29-41.

Kear, D.; Schofield, J. C. 1958: Te Kuiti Group. New Zealand Journal of Geology and Geophysics 2: 685-717.

King, P. R.; Naish, T. R.; Browne G. H.; Field, B. D.; Edbrooke, S. W. comp. 1999: Cretaceous to Recent sedimentary patterns in New Zealand. Institute of Geological \& Nuclear Sciences Folio Series 1. Lower Hutt, Institute of Geological $\&$ Nuclear Sciences Ltd.

Kingma, J. T.; Speden, I. G. 1978: Eastern North Island. In: Suggate, R. P.; Stevens, G. R.; Te Punga, M. T. ed. The geology of New Zealand, Vol. II. Wellington, Government Printer. Pp. 369-375.

Laird, M. G. 1993: Cretaceous continental rifts: New Zealand region. In: Ballance, P. F. ed. South Pacific sedimentary basins. Sedimentary basins of the world 2. Amsterdam, Elsevier. Pp. 37-49.
McLennan, S. M; Taylor, S. R.; McCulloch, M. T.; Maynard, J. B. 1990: Geochemical and Nd-Sr isotopic composition of deep-sea turbidites: crustal evolution and plate tectonic associations. Geochimica et Cosmochimica Acta 54: 20152050.

Mortimer, N. 1995a: Triassic to Early Cretaceous tectonic evolution of New Zealand terranes: a summary of recent data and an integrated model. In: Mauk, J. L.; St George, J. D. $e d$. Proceedings of the 1995 PACRIM Congress, Auckland, New Zealand. Australasian Institute of Mining and Metallurgy Publication Series 9/95: 401-406. Victoria, Australasian Institute of Mining and Metallurgy.

Mortimer, N. 1995b: Origin of the Torlesse Terrane and coeval rocks, North Island, New Zealand. International Geology Review 36: 891-910.

Mortimer, N.; Tulloch, A. J.; Ireland, T. R. 1997: Basement geology of Taranaki and Wanganui Basins, New Zealand. New Zealand Journal of Geology and Geophysics 40: 223-236.

Muir, R. J.; Weaver, S. D.; Bradshaw, J. D.; Eby, G. N.; Evans, J. A. 1995: The Cretaceous Separation Point batholith, New Zealand: granitoid magmas formed by melting of mafic lithosphere. Journal of the Geological Society of London 152: 689-701.

Nelson, C. S. 1978: Stratigraphy and paleontology of the Oligocene Te Kuiti Group, Waitomo County, South Auckland, New Zealand. New Zealand Journal of Geology and Geophysics 21: 553-594.

Nesbitt, H. W.; Young, G. M. 1982: Early Proterozoic climates and plate motions inferred from major element chemistry of lutites. Nature 299: 715-717.

Nesbitt, H. W.; Young, G. M. 1989: Formation and diagenesis of weathering profiles. Journal of Geology 97: 129-147.

Roser, B. P.; Korsch, R. J. 1986: Determination of tectonic settings of sandstone-mudstone suites using $\mathrm{SiO}_{2}$ content and $\mathrm{K}_{2} \mathrm{O} / \mathrm{Na}_{2} \mathrm{O}$ ratio. Journal of Geology 94: 635-650.

Roser, B. P.; Korsch, R. J. 1988: Provenance signatures of sandstone-mudstone suites determined using discriminant function analysis of major-element data. Chemical Geology 67: 119-139.

Roser, B. P.; Korsch, R. J. 1999: Geochemical characterization, evolution and source of a Mesozoic accretionary wedge: the Torlesse terrane, New Zealand. Geological Magazine 136: 493-512.

Skinner, D. N. B. 1972: Subdivision and petrology of the Mesozoic rocks of Coromandel (Manaia Hill Group). New Zealand Journal of Geology and Geophysics 15: 203-227.

Skinner, D. N. B. 1976: Sheet N40 and part sheets N35, N36 and N39-northern Coromandel. 1 map and booklet 28 p. Geological map of New Zealand 1:63 360. Wellington, Department of Scientific and Industrial Research.

Skinner, D. N. B. 1978: Coromandel-Waikato-King Country. In: Suggate, R. P.; Stevens, G. R.; Te Punga, M. T. ed. The geology of New Zealand, Vol. I. Wellington, Government Printer. Pp. 266-267.

Skinner, D. N. B. 1993: Geology of Coromandel Harbour area. Scale 1:50 000. Institute of Geological \& Nuclear Sciences geological map 4.1 sheet and 44 p.

Suggate, R. P.; Stevens, G. R.; Te Punga, M. T. ed. 1978: The geology of New Zealand. Wellington, Government Printer. 820 p.

Surdam, R. C.; Dunn, T. L.; Heasler, H. P.; MacGowan, D. B. 1989: Porosity evolution in sandstone/shale systems. In: Hutcheon, I. E. ed. Burial diagenesis. Mineralogical Association of Canada Short Course 15: 61-134. Montreal, Quebec, Mineralogical Association of Canada.

Taylor, S. R.; McLennan, S. M. 1985: The continental crust: its composition and evolution. Oxford, Blackwell Scientific. $312 \mathrm{p}$. 